\title{
Obesity and thermogenesis related to the consumption of caffeine, ephedrine, capsaicin and green tea
}

\author{
Citation for published version (APA):
}

Diepvens, K., Westerterp, K. R., \& Westerterp-Plantenga, M. S. (2007). Obesity and thermogenesis related to the consumption of caffeine, ephedrine, capsaicin and green tea. American Journal of Physiology-regulatory Integrative and Comparative Physiology, 292(1), R77-R85. https://doi.org/10.1152/ajpregu.00832.2005

Document status and date:

Published: 01/01/2007

DOI:

10.1152/ajpregu.00832.2005

Document Version:

Publisher's PDF, also known as Version of record

\section{Document license:}

Taverne

\section{Please check the document version of this publication:}

- A submitted manuscript is the version of the article upon submission and before peer-review. There can be important differences between the submitted version and the official published version of record. People interested in the research are advised to contact the author for the final version of the publication, or visit the DOI to the publisher's website.

- The final author version and the galley proof are versions of the publication after peer review.

- The final published version features the final layout of the paper including the volume, issue and page numbers.

Link to publication

\footnotetext{
General rights rights.

- You may freely distribute the URL identifying the publication in the public portal. please follow below link for the End User Agreement:

www.umlib.nl/taverne-license

Take down policy

If you believe that this document breaches copyright please contact us at:

repository@maastrichtuniversity.nl

providing details and we will investigate your claim.
}

Copyright and moral rights for the publications made accessible in the public portal are retained by the authors and/or other copyright owners and it is a condition of accessing publications that users recognise and abide by the legal requirements associated with these

- Users may download and print one copy of any publication from the public portal for the purpose of private study or research.

- You may not further distribute the material or use it for any profit-making activity or commercial gain

If the publication is distributed under the terms of Article 25fa of the Dutch Copyright Act, indicated by the "Taverne" license above, 


\title{
CALL FOR PAPERS $\mid$ Physiology and Pharmacology of Temperature Regulation
}

\section{Obesity and thermogenesis related to the consumption of caffeine, ephedrine, capsaicin, and green tea}

\author{
Kristel Diepvens, Klaas R. Westerterp, and Margriet S. Westerterp-Plantenga \\ Department of Human Biology, Maastricht University, Maastricht, The Netherlands
}

\begin{abstract}
Diepvens, Kristel, Klaas R. Westerterp, and Margriet S. Westerterp-Plantenga. Obesity and thermogenesis related to the consumption of caffeine, ephedrine, capsaicin, and green tea. Am J Physiol Regul Integr Comp Physiol 292: R77-R85, 2007. First published July 13, 2006; doi:10.1152/ajpregu.00832.2005.-The global prevalence of obesity has increased considerably in the last decade. Tools for obesity management, including caffeine, ephedrine, capsaicin, and green tea have been proposed as strategies for weight loss and weight maintenance, since they may increase energy expenditure and have been proposed to counteract the decrease in metabolic rate that is present during weight loss. A combination of caffeine and ephedrine has shown to be effective in long-term weight management, likely due to different mechanisms that may operate synergistically, e.g., respectively inhibiting the phosphodiesterase-induced degradation of cAMP and enhancing the sympathetic release of catecholamines. However, adverse effects of ephedrine prevent the feasibility of this approach. Capsaicin has been shown to be effective, yet when it is used clinically it requires a strong compliance to a certain dosage, that has not been shown to be feasible yet. Also positive effects on body-weight management have been shown using green tea mixtures. Green tea, by containing both tea catechins and caffeine, may act through inhibition of catechol O-methyl-transferase, and inhibition of phosphodiesterase. Here, the mechanisms may also operate synergistically. In addition, tea catechins have antiangiogenic properties that may prevent development of overweight and obesity. Furthermore, the sympathetic nervous system is involved in the regulation of lipolysis, and the sympathetic innervation of white adipose tissue may play an important role in the regulation of total body fat in general.
\end{abstract}

sympathetic nervous system; energy expenditure; body weight; adverse effects

OVERWEIGHT AND OBESITY REPRESENT a threat to the health of populations in an increasing number of countries (131). Obesity is the outcome of a prolonged positive energy balance, due to an excess energy intake over energy expenditure (EE), or vice versa. A negative energy balance is needed to produce weight loss and can be achieved by either decreasing intake or increasing expenditure. Tools for obesity management, including agents like caffeine, ephedrine, capsaicin, and green tea have been proposed as strategies for weight loss and weight maintenance, since they may increase EE and have been proposed to counteract the decrease in metabolic rate that is present during weight loss.

This review examines the thermogenic properties of caffeine, ephedrine, capsaicin, and green tea in relation to the regulation of body weight. Furthermore, we discuss the role of the sympathetic nervous system in obesity.

Thermogenic Properties of Caffeine, Ephedrine, Capsaicin, and Green Tea in the Perspective of Body Weight Regulation

Evidence for the mechanisms behind thermogenic properties of caffeine, ephedrine, capsaicin, and green tea is controversial and will be discussed more thoroughly in the final discussion.

Address for reprint requests and other correspondence: K. Diepvens, Maastricht Univ., Dept. of Human Biology, P.O. Box 616, NL-6200 MD Maastricht, The Netherlands (e-mail: K.Diepvens@HB.Unimaas.NL).
Here, a few most likely mechanisms for the observed thermogenic properties are included where appropriate.

Caffeine. Caffeine as a thermogenic agent has been investigated for potential use in body weight reduction. A possible mechanism by which caffeine affects thermogenesis involves inhibiting the phosphodiesterase-induced degradation of intracellular cyclic AMP (cAMP) (31). Presently, possible evidence for the metabolic response to caffeine from mechanisms involving catecholaminergic stimulation of adipocyte or other cellular metabolism seems less convincing $(17,61,122)$ (see also DISCUSSION). Dulloo et al. (39) concluded that the ability of methylxanthines to potentiate the thermogenic effect of ephedrine, particularly under conditions of caloric restriction, involves a minor contribution of adenosine antagonism, but it could mainly be explained by the inhibition of phosphodiesterase activity. Furthermore, it has been reported that the thermogenic impact of methylxanthines may be due to stimulation of substrate cycles like the Cori cycle (conversion of glycogen and glucose to lactate) and FFA-triglyceride cycle (7, 8, 133). Hepatic thermogenic processes triggered by lactate and the formation of triglyceride after hepatic reesterfication may explain the thermogenic contribution to the effect of caffeine (8).

The stimulatory effect of caffeine on thermogenesis in man is well established $(1,8,17,33,57)$. Reduced food intake after caffeine consumption has been shown as well $(90,117)$. Thus 
caffeine can influence both EE and energy intake. Although a nonhuman animal model showed that caffeine decreased body fat deposition (23), long-term intervention studies in humans showed no effect of caffeine consumption on body weight $(5$, $85,128)$. A possible explanation for the lack of a long-term effect of caffeine is the development of insensitivity to its effects.

Ephedrine. Ephedra sinica is a shrub native to China and Mongolia that contains sympathomimetic compounds referred to as ephedra alkaloids (101). Ephedra contains four isomers, of which ephedrine is believed to be the alkaloid most responsible for the thermogenic effects (123). The thermogenic effect of ephedrine can be potentiated by caffeine $(5,37)$. Ephedrine mediates its thermogenic effects, primarily by enhancement of sympathetic neuronal release of norepinephrine (NE) and epinephrine $(31,39)$. However, in vitro research showed that ephedrine stimulates brown adipocyte respiration directly via $\beta$-adrenoceptors (21). The rapid development of tolerance to the pressor effects, but not to its thermogenic effects, suggests that ephedrine influences the cardiovascular system via adrenergic mechanisms not entirely similar to those mediating thermogenesis. The suggestion, therefore, arises that thermogenesis is mediated only partly by classical adrenoceptors (38).

In a nonhuman animal study, treatment with ephedrine caused an increase in EE of about $10 \%$, which resulted in body weight loss and body fat loss (36). Intervention studies in humans showed similar effects $(87,88,105)$. Thus ephedrine stimulates EE, and the effect is maintained for several months after administration (6).

The long-term use of ephedrine, however, does not necessarily lead to an increase in weight loss. Authors of the studies with favorable effects also reported studies without these effects $(5,86)$. The disparate findings may be due to the independent thermogenic actions of ephedrine, which enhance sympathetic neuronal release of NE, to the stimulating effects of the $\beta$-adrenoceptors, or adaptation to epinephrine after some months, unless ephedrine is combined with caffeine (see below).

Ephedrine and caffeine. The thermogenic effect of ephedrine can be markedly potentiated by methylxanthines, such as caffeine. Indeed, nonhuman animal studies showed that the effect after an ephedrine/caffeine mixture was larger than that with ephedrine or caffeine alone $(35,36,92,121)$.

The interaction between ephedrine and caffeine in the effect on $\mathrm{EE}$ and weight loss has been confirmed in human studies (5, $7,14,59,77,113,114$ ) [see Astrup (4) for a review]. In a long-term study (6 mo) of 167 obese subjects, the ephedrine/ caffeine mixture group lost significantly more weight than the placebo group (13). Thus, with respect to the longer-term use of caffeine or ephedrine, it is theoretically recommended to combine these agents, based upon several longer-term experiments with a positive outcome and likely due to synergistic mechanisms. However, because of adverse effects (see below), the Food and Drug Administration (FDA) has banned the sale of ephedra-containing dietary supplements.

Capsaicin. Capsaicin is the major pungent principle in red hot peppers. In rats, capsaicin has been reported to increase thermogenesis by dose dependently enhancing catecholamine secretion from the adrenal medulla $(65,127)$. It has been suggested that specific capsaicin-sensitive neurons are involved in this process (126). In addition, a warming action via adrenal catecholamine secretion is induced (64). Osaka et al. (84) reported that the critical locus that mediates the capsaicininduced thermogenesis in the brain stem is in the premotor area of sympathoadrenal preganglionic neurons, that is, the rostral ventrolateral medulla.

Yoshioka et al. (136) observed in humans a larger increase in EE immediately after a meal containing red pepper vs. control. In addition, both nonhuman animal and human studies showed that the increase in thermogenesis is abolished after administration of $\beta$-adrenergic blockers such as propranolol (65), which implies that capsaicin-induced thermogenesis is likely based upon $\beta$-adrenergic stimulation.

The nonhuman animal studies also showed that injection or oral treatment with capsaicin stimulates the sympathetic nervous system activity $(65,126,127,134)$. Thus administration of capsaicin favors an increase in lipid mobilization and a decrease in adipose tissue mass $(63,65)$.

In studies with humans, red pepper induced a reduction of ad libitum food intake and an increased postprandial EE and lipid oxidation $(56,129,135-138)$. Participants in a 2-wk study, in which capsaicin was administered in combination with green tea and chicken essence, showed a reduction in body fat (119). In a long-term study, a relatively more sustained fat oxidation in the capsaicin group was observed compared with the placebo group, consistent with nonhuman animal studies (73). Weight regain, however, was similar in both groups and was assumed to be due to lack of full compliance, that is, ingestion of half the prescribed dosage (73). Thus the longer-term use of capsaicin may be limited by its strong pungency. A possible solution for this may be using CH-19 Sweet. CH-19 Sweet is the fruit of a nonpungent cultivar of pepper. In a human study, CH-19 Sweet increased oxygen consumption and body temperature. These effects are thought to be caused by capsiate, which has a structure similar to capsaicin but no pungency $(81,82)$.

Green tea. Green tea contains high quantities of several polyphenolic components, such as epicatechin, epicatechin gallate, epigallocatechin, and, the most abundant and probably the most pharmacologically active, epigallocatechin gallate (EGCG) (62). The catechins in green tea may stimulate thermogenesis and fat oxidation through inhibition of catechol O-methyl-transferase (COMT), an enzyme that degrades NE (15). In humans, Dulloo et al. (32) showed that a green tea extract results in an increase in EE and fat oxidation in the short-term (32). Green tea extract also contains caffeine. As described above, caffeine has been shown to stimulate thermogenesis. The fact that a green tea extract stimulates thermogenesis cannot be completely attributed to its caffeine content because the thermogenic effect of green tea is greater than an equivalent amount of caffeine (32). Indeed, studies in humans showed that green tea has thermogenic properties beyond that explained by its caffeine content per se $(11,32)$. Thus green tea, by containing both tea catechins and caffeine, may act at different steps of modulatory pathways, that is, via phosphodiesterase, and via COMT, and in this way exert a thermogenic and possibly an antiobesity effect $(32,40,62)$.

Studies in rats and mice showed an EGCG-induced reduction in food intake and/or an increase in $\operatorname{EE}(24,62,140)$. Studies conducted over 3 mo or more showed that the consumption of tea catechins induces a notable reduction of body 
weight and body fat $(22,53,78,79,120)$ and increases EE (52).

Green tea has also successfully been applied as an agent to limit weight regain after weight loss $(67,128)$. Here, the suggested mechanism is that green tea ingestion during a low-energy diet offsets the expected reduction in EE. Indeed, resting $\mathrm{EE}$ as a function of fat-free mass and fat mass did not decrease significantly over time when green tea was ingested together with a low-energy-diet (27).

A different approach to treatment of overweight and prevention of obesity is represented by the antiangiogenic effects of EGCG. It appears that modulation of angiogenic factors during development of adipose tissue plays an important functional role in prevention of obesity (125). The importance of this role is indicated by the phenomenon that angiogenic factors are elevated in overweight and obese individuals (107). Even an angiogenesis inhibitor, TNP-470, has been shown to prevent diet-induced and genetic obesity in mice (18). Findings suggest that adipose tissue growth is dependent on angiogenesis, which is similar to growth and organogenesis in other tissues. Leptin also appears to play a role in this process, as adipogenesis and angiogenesis are tightly correlated during the fat mass development. In vitro experiments have shown that leptin, via activation of the endothelial Ob-R, generates a growth signal involving a tyrosine kinase-dependent intracellular pathway and promotes angiogenic processes. It is speculated that this leptin-mediated stimulation of angiogenesis might represent not only a key event in the settlement of obesity but may also contribute to the modulation of growth under physiological and pathophysiological conditions (16).

From this viewpoint, inhibition of angiogenesis may be a different pathway to prevent further development of overweight or obesity. Indeed, a mixture containing ascorbic acid, lysine, proline, and green tea extract appeared to have an inhibitory effect on critical parameters in angiogenesis (98). Mechanisms of antiangiogenic effects may involve inhibition of endothelial cell proliferation in response to stimulation with angiogenic growth factors (66). This can be exerted by inhibition of vascular endothelial growth factor (VEGF) receptors and suppression of vascular endothelial cadherin and protein kinase B (Akt) phosphorylation (111). Activation of certain transcription factors, such as NF- $\mathrm{kB}$ and E26 transformationspecific- 1 and activating protein- 1 is also blunted (69), and the production of metalloproteinases necessary for endothelial cell migration and invasion is attenuated $(46,83,132)$. In addition, EGCG can also inhibit the production of VEGF, basic fibroblast growth factor, and interleukin-8 (IL-8) $(102,103,118)$.

\section{Adverse Effects of Thermogenic Agents}

Caffeine appears to be a safe thermogenic agent for weight control. In adults, the short-term lethal dose for caffeine is estimated at 5-10 g per day (either intravenously or orally), which is equivalent to 75 cups of coffee, 125 cups of tea, or 200 cola beverages (26). Long-term ingestion of caffeine has been suggested to have some minor adverse effects on human health. Astrup et al. (8) observed only small and insignificant changes in blood pressure and pulse rate after 100 and $200 \mathrm{mg}$ caffeine. In contrast, $400 \mathrm{mg}$ caffeine significantly increased systolic and diastolic blood pressure by an average value of 6.3 $\mathrm{mmHg}$. Furthermore, after $400 \mathrm{mg}$ caffeine, significantly more subjects reported side effects such as palpitation, anxiety, headache, restlessness, dizziness compared with placebo (8). Robertson et al. (96) administrated $250 \mathrm{mg}$ oral caffeine to nine subjects who were not used to coffee. Systolic blood pressure increased $10 \mathrm{mmHg} 1 \mathrm{~h}$ after caffeine consumption. Heart rate showed a decrease after the first hour followed by an increase above baseline after 2 h (96). However, in a subsequent study that examined the chronic effects of caffeine ingestion (150 $\mathrm{mg}$ /day for 7 days), tolerance to these effects was developed after 1-4 days (97). Thus no long-term effects of caffeine on blood pressure, heart rate, or plasma rennin activity were demonstrated. Furthermore, in the short term, Bracco et al. (17) did not find a significantly altered heart rate during the day after $4 \mathrm{mg}$ caffeine per $\mathrm{kg}$ body weight was consumed 5 times daily. Accordingly, the use of caffeine is relatively safe, as it is quite certain that, although acute caffeine consumption may alter some cardiovascular variables, chronic ingestion of caffeine has little or no health consequences.

In contrast, a number of safety concerns have been raised about the use of ephedrine and ephedrine-containing mixtures. In an FDA-sponsored analysis, Haller and Benowitz (50) reviewed 140 reports of adverse events related to the use of dietary supplements containing ephedra alkaloids. They concluded that the use of ephedra alkaloids may pose a health risk to some persons, since ephedra and related alkaloids have been associated with adverse cardiovascular events (50). Haller et al. (51) found that consumption of two doses ( $5 \mathrm{~h}$ apart) of an ephedra/caffeine mixture $(325 / 90 \mathrm{mg})$ resulted in persistent increases in heart rate, blood pressure, and glucose concentrations, and decreases in potassium concentrations. Further evidence was found in a meta-analysis by Shekelle et al. (106) to conclude that ephedrine and ephedra are associated with increased risk of psychiatric symptoms, autonomic symptoms, upper gastrointestinal symptoms, and heart palpitations (106). Given the frequency of reports of adverse cardiovascular effects, the FDA has banned the sale of ephedra-containing dietary supplements (91). Other research however, observed no significant adverse effects or only temporary minor adverse effects with the consumption of ephedra alkaloids $(5,13,14$, $94,113,114)$. Given these contrary results, consideration should be given to whether these adverse effects occur at a higher rate than that of a matched, untreated group (13). Thus the use of products containing ephedra alkaloids remains controversial and warrants further research.

As mentioned previously, the long-term use of capsaicin may be limited by its strong pungency. An alternative is using CH-19 Sweet, the nonpungent cultivar of red pepper (82).

Green tea has been widely consumed in China and Japan for many centuries and is regarded as safe. A possible side effect of green tea consumption is a minor increase in blood pressure as seen by Berube-Parent et al. (11). They observed a nonsignificant increase $(7 \mathrm{mmHg})$ in $24 \mathrm{~h}$ systolic blood pressure accompanied by a significant increase $(5 \mathrm{mmHg})$ in $24-\mathrm{h}$ diastolic blood pressure. No increase in heart rate was seen (11). This small short-term increase in blood pressure induced by green tea might be neglected since systolic blood pressure, diastolic blood pressure, and heart rate were not affected by green tea in other short-term (32) or long-term research $(22,27)$.

Taking adverse effects into account, although the use of ephedrine or capsaicin in treatments seems effective, it is 
contraindicated by adverse effects of these agents. Thus the remaining combination of caffeine and green tea may be recommended for body-weight management.

\section{Discussion: Obesity and Sympathetic Nervous System Activity}

Convincing evidence for body-weight management using caffeine, green tea, ephedrine, and capsaicin has been shown. Caffeine stimulates thermogenesis by inhibiting the phosphodiesterase-induced degradation of cAMP, and catechins in green tea through inhibition of COMT, an enzyme that degrades NE. Moreover, tea catechins have antiangiogenic effects that may prevent development of overweight and obesity. The thermogenic effect of caffeine can be potentiated by ephedrine, which mediates its effects by enhancement of sympathetic neuronal release of $\mathrm{NE}$, or by stimulating $\beta$-adrenoceptors directly. Furthermore, capsaicin may increase thermogenesis by enhancing catecholamine secretion from the adrenal medulla.

The sympathetic nervous system (SNS) has been considered an essential component of the autonomic nervous system, playing an important role in maintaining energy homeostasis by hormonal and neural control $(28,30,41)$. The SNS has been described as a complex regulatory system, involving direct effects of sympathetic nerves, which supply most body tissues and, indirect effects of the catecholamines, epinephrine, and, to a lesser extent, NE, which are released into the blood from the adrenal medulla (74). It is important to realize that the SNS does not produce uniform activation of all body tissues, which have a sympathetic nerve supply, but rather that in any particular situation, there is selective activation of specific tissues or systems, with either no effect or even inhibition of other areas (74). It should be appreciated, therefore, that renal or brown fat or muscle changes in electrophysiological activity of efferent nerves innervating these tissues is specific to that tissue, as well as the NE turnover. In addition, there are not only differences in SNS outflow to different tissues but also within the same tissue type (29). For instance, among white adipose tissue (WAT) depots in humans, the measures of sympathetic drive can be quite different (29).

Sympathetic activity to effector organs of metabolism is considered to be a key factor for maintenance of body weight (29). Effects imply thermogenic effects of increased sympathetic activity, as well as regulation of fat metabolism.

Examples of thermogenic effects are sympathomimetic-induced changes in energy balance through increases in EE (3, 20,109 ). It has been shown that SNS activity (determined by NE concentrations) modulates resting EE (resting metabolic rate measured after an overnight fast), the largest component of daily EE $(100,112)$. Since NE has the ability to increase the use of ATP, for example, through ion pumping and substrate cycling, or to increase the rate of mitochondrial oxidation with poor coupling of ATP synthesis leading to increased heat production, it is speculated that the SNS is involved in thermogenesis $(30,41)$. Indeed, human studies have demonstrated that thermogenesis, measured by whole body calorimetry, increased significantly during the infusion of NE or epinephrine $(68,108)$. Tissue-specific effects included an increase in skeletal muscle oxygen uptake, and the triglyceride-fatty acid cycle contributed to the NE-induced increase in EE of non- muscular tissue in healthy, normal-weight subjects $(68,108)$. The thermogenic response to catecholamines has been shown to be mediated by a combination of $\beta 1-, \beta 2-$, and $\beta 3$-receptors (4). The activity of the SNS has been assessed in several ways, including plasma catecholamine levels, catecholamine turnover, urinary catecholamine excretion, and muscle sympathetic nerve activity. However, results are contradictory because of methodological differences $(42,139)$. For instance, the viewpoint of Eikelis and Esler (42) is that earlier ideas that SNS activity is low in human obesity, contributing to weight gain through the absence of sympathetically mediated thermogenesis should be discounted. Application of new techniques, such as sympathetic nerve recording and isotope dilution, quantifying neurotransmitter release from sympathetic nerves, have shown that peripheral sympathetic outflows to, for example, the kidneys and skeletal muscle vasculature are activated in obese humans (42). In addition, according to Eikelis and Esler (42), the demonstration that the suppressed sympathetic tone characterizing animal models of obesity-largely based on brown fat recordings (19) -is not present in humans weakens the case for the use of $\beta 3$-adrenergic agonists as thermogenic agents to facilitate weight loss. Moreover, Dulloo (31) proposed that a possible mechanism by which caffeine affects thermogenesis involves inhibiting the phosphodiesterase-induced degradation of intracellular cyclic AMP (cAMP) and to a lesser extent antagonizing adenosine-inhibitory effects on NE release. Also, other human research did not observe a smaller thermogenic effect after treatment with $\beta$-blockers (61). Thus thermogenesis can be affected by caffeine and green teacaffeine mixtures via pathways different from antagonizing adenosine-inhibitory effects on NE release. These pathways are inhibiting the phosphodiesterase-induced degradation of intracellular cAMP (caffeine) and inhibition of COMT, an enzyme that degrades NE (catechins).

From our viewpoint, stronger evidence is present with respect to sensitivity of SNS to positive energy balances. In nonhuman animals, Landsberg and Young (70-72) showed that SNS activation is a key element of the counterregulatory response to excessive food intake in heart and brown adipose tissue. Moreover, human studies have demonstrated that SNS activation is an important aspect of the response to overfeeding $(10,34,76)$. McCargar et al. (76) showed that urinary NE levels were increased during overeating, suggesting sympathetic activation. SNS activation increases thermogenesis and wastes excess energy as heat, and thereby compensates for surplus energy intake. The result is the prevention of body weight gain. This hypothesis is also supported by Vaz et al. (124) and Grassi et al. (48), who indicated in humans that, on the basis of sympathetic nerve recording in skeletal muscle and skin areas and isotope dilution-derived measurements of renal and cardiac NE release to plasma, human obesity is accompanied by activation of the SNS rather than its suppression. In human obesity, the whole body NE spillover rate, which is an indication of overall sympathetic activity, is typically normal $(89,99,124)$. Renal NE spillover, indicative of renal sympathetic activity is approximately doubled, while cardiac sympathetic activity is reduced $(29,89,99,124)$.

This renal sympathetic activation is primarily pathophysiological in obesity-related hypertension. The higher renal and lower cardiac sympathetic nerve activity in overweight people represents a differentiation of central nervous system sympa- 
thetic nerves and reduced cardiac sympathetic nerve firing. One of the candidates for activation of renal sympathetic outflow is hyperleptinemia, given that administration of leptin in animal models increases renal sympathetic activity (80).

Only during negative energy balance, SNS activity seems to be negatively affected. Spraul et al. (110) measured fasting skeletal muscle sympathetic nerve activity and its relation with EE. In this condition, obese subjects are acutely in a negative energy balance. They showed in obesity-prone subjects that a low resting muscle sympathetic nerve activity (an indicator of reduced SNS activity) was related to a reduced EE, which is responsible for weight gain and obesity (110). Furthermore, a negative energy balance was associated with a reduction of sympathetic activity at the muscular level, which reduces resting $\mathrm{EE}$ and thus prolongs survival. In addition, a negative energy balance was associated with an increased lipolysis in response to catecholamines in adipose tissue $(2,12,47)$.

The SNS undoubtedly plays a role in the regulation of fat metabolism. Given the importance of muscle lipolysis for EE, low sympathetically mediated $\mathrm{EE}$ is considered to be a risk factor for body weight gain (93). Several studies, however, have reported increased muscle sympathetic nerve activity (MSNA) in obese subjects $(49,104)$, while total body NE spillover is similar in lean and obese subjects (99). Nevertheless, the combination of these effects in a compensatory mechanism is possible, that is, an initially low sympathetic activity results in fat accumulation, which in turn augments sympathetic outflow through compensatory endocrine mechanisms (29). One such compensatory mechanism could be increased leptin release from larger fat depots, an endocrine signal known to increase sympathetic activity via hypothalamic mechanisms in rats $(54,55)$ (see below). Moreover, it should be stressed that sympathetic excitation may be an unspecific secondary consequence of obesity, e.g., the obstructive sleep apnea syndrome that increases MSNA (80). Thus when discussing the role of sympathetic activity in the control of fat and body mass, it must be taken into account that the findings of unaltered total body NE spillover and increased MSNA in obesity do not unequivocally exclude the possibility that a selective reduction in sympathetic discharge to fat depots could contribute to an accumulation of fat mass and weight gain in general (29).

Physiological and neurological evidence strongly suggests that the SNS is involved in the regulation of lipolysis. Bartness and Bamshad (9) reviewed the SNS innervation of WAT. They suggest that in addition to the stimulation of lipolysis by catecholamines in vitro (130), implying that lipid mobilization may be primarily controlled via blood-borne catecholamines, SNS innervation of WAT takes place directly (9). They provide extensive evidence that supports the role of the SNS innervation of WAT in lipid mobilization (9). The physiological evidence includes electrophysiological recording, denervation studies, and electrical stimulation of the nerves innervating this tissue. The neuroanatomical evidence that supports the role of the SNS innervation of WAT is highlighted by the use of a viral transneuronal tract tracer to define the chain of functionally connected neurons that comprise the SNS outflow from brain to WAT. Bartness and Bamshad (9) conclude that the direct innervation of WAT by the SNS could play a role in the regulation of total body fat in general $(9,29)$. There are precious few studies, however, where WAT electrical activity or NE turnover is measured. When measured, it is often the case that among WAT depots, these measures of sympathetic drive can be quite different. Thus the role of sympathetic nerves in the control of lipolysis in human WAT, which is sparsely innervated, has not been fully clarified (29).

Dodt et al. (29) provide a human in vivo model for further studies of neural control of lipolysis. They combined intraneural electrical stimulation of human cutaneous nerve fascicles supplying WAT on the thigh with microdialytic evaluation of glycerol release within the territory innervated by the stimulated nerve fascicle. They demonstrated that lipolysis can be neurally induced and that this neural effect can be blunted in obese subjects (29). These are the first steps to clarify the discrepancies between in vivo and in vitro findings concerning human lipolysis, that is, that lean and obese do not differ in relative lipolysis (60), but that isolated fat cells from obese subjects show an increased basal lipolysis, a reduced antilipolytic response to insulin and to $\beta$-adrenoceptor stimulation (29).

As indicated above, there may be a two-way interaction between leptin and the SNS, perhaps constituting a regulatory feedback loop, with leptin acting within the hypothalamus to cause activation of central sympathetic outflow and stimulation of adrenal medullary release of epinephrine (45) and conversely with the SNS-inhibiting leptin release (115).

It is assumed, from the increases in renal nerve activity, as well as brown fat, that leptin turns on the SNS outflow (25). This is likely very tissue-specific, as leptin administration did not significantly affect NE turnover in WAT (25). On the other hand, it has been demonstrated that the SNS inhibits leptin release from WAT $(95,115,116)$. In addition, Ramsey et al. (92) showed that administration of an ephedrine/caffeine mixture resulted in decreased serum leptin concentrations in monkeys. Others have shown that activation of $\beta_{3}$-adrenergic receptors suppresses leptin gene expression $(75,95,116)$. Accordingly, the stimulating effect of sympathomimetic agents on the SNS may lead to a downregulation of leptin release (58, $92,128)$. Consequent decreased leptin concentrations may increase food intake, which would diminish the effect of SNS activation on weight loss. However, the satiety effect of, for example, caffeine appeared to dominate the possible effect of downregulated leptin in overweight subjects, since the subjects with highest habitual caffeine intake were significantly more satiated and lost more weight (128). Findings by Eikelis et al. (44) in humans, however, do not support the proposition that the SNS inhibits leptin release. They examined the leptin overflow from different organs and reported that whole body leptin secretion rate correlated directly with whole body and renal NE spillover, indicating that hyperleptinemia may be the prime mover underlying the sympathetic nervous activation present in human obesity and particularly in the sympathetic outflow to the kidneys (43). In addition, they found that the whole body leptin secretion rate was unrelated to cardiac NE spillover or to the secretion of epinephrine.

Taken together, evidence for the following thermogenic mechanisms has been shown: caffeine stimulates thermogenesis by inhibiting the phosphodiesterase-induced degradation of cAMP, and catechins in green tea through inhibition of COMT. Moreover, tea catechins have antiangiogenic effects, which may prevent development of overweight and obesity. This is related to leptin, since leptin has been shown to promote 
angiogenesis. Ephedrine and capsaicin mediate their effects by enhancement of sympathetic release of catecholamines or by stimulating $\beta$-adrenoceptors directly (ephedrine). In addition, the SNS is involved in the regulation of lipolysis, and the SNS innervation of WAT may play an important role in the regulation of total body fat in general.

In conclusion, treatment of overweight, and thus prevention of obesity, requires a multifactorial approach. This may be possible by applying sympathomimetics such as caffeine, ephedrine, capsaicin, and green tea. A combination of caffeine and ephedrine has shown to be effective in long-term weight management, likely due to different mechanisms that may operate synergistically, for example, inhibiting the phosphodiesterase-induced degradation of cAMP and enhancing the sympathetic release of catecholamines, respectively. However, adverse effects of ephedrine prevent the feasibility of this approach. Capsaicin has been shown to be effective, yet when it is used clinically, it requires a strong compliance to a certain dosage, which has not been shown to be feasible yet. Also, positive effects on body-weight management have been shown using green tea. Green tea, by containing both tea catechins and caffeine, may act through inhibition of COMT and inhibition of phosphodiesterase. Here, the mechanisms may also operate synergistically. In addition, tea catechins have antiangiogenic properties that may prevent development of overweight and obesity. This is related to leptin, as leptin has been shown to promote angiogenesis. Furthermore, the SNS is involved in the regulation of lipolysis, and the SNS innervation of WAT may play an important role in the regulation of total body fat in general.

\section{REFERENCES}

1. Acheson KJ, Zahorska-Markiewics B, Pittet P, Anantharaman K, and Jequier E. Caffeine and coffee: their influence on metabolic rate and substrate oxidation in normal weight and obese individuals. Am J Clin Nutr 33: 989-997, 1980.

2. Andersson B, Elam M, Wallin BG, Bjorntorp P, and Andersson OK. Effect of energy-restricted diet on sympathetic muscle nerve activity in obese women. Hypertension 18: 783-789, 1991.

3. Astrup A. The sympathetic nervous system as a target for intervention in obesity. Int J Obes Relat Metab Disord 19 Suppl 7: S24-S28, 1995.

4. Astrup A. Thermogenic drugs as a strategy for treatment of obesity. Endocrine 13: 207-212, 2000.

5. Astrup A, Breum L, Toubro S, Hein P, and Quaade F. The effect and safety of an ephedrine/caffeine compound compared to ephedrine, caffeine and placebo in obese subjects on an energy-restricted diet. A double blind trial. Int J Obes 16: 269-277, 1992.

6. Astrup A, Lundsgaard C, Madsen J, and Christensen NJ. Enhanced thermogenic responsiveness during chronic ephedrine treatment in man. Am J Clin Nutr 42: 83-94, 1985.

7. Astrup A and Toubro S. Thermogenic, metabolic, and cardiovascular responses to ephedrine and caffeine in man. Int J Obes Relat Metab Disord 17 Suppl 1: S41-S43, 1993.

8. Astrup A, Toubro S, Cannon S, Hein P, Breum L, and Madsen J. Caffeine: a double-blind, placebo-controlled study of its thermogenic, metabolic, and cardiovascular effects in healthy volunteers. Am J Clin Nutr 51: 759-767, 1990.

9. Bartness TJ and Bamshad M. Innervation of mammalian white adipose tissue: implications for the regulation of total body fat. Am J Physiol Regul Integr Comp Physiol 275: R1399-R1411, 1998.

10. Bazelmans J, Nestel PJ, O'Dea K, and Esler MD. Blunted norepinephrine responsiveness to changing energy states in obese subjects. Metabolism 34: 154-160, 1985.

11. Berube-Parent S, Pelletier C, Dore J, and Tremblay A. Effects of encapsulated green tea and Guarana extracts containing a mixture of epigallocatechin-3-gallate and caffeine on $24 \mathrm{~h}$ energy expenditure and fat oxidation in men. Br J Nutr 94: 432-436, 2005.
12. Bobbioni-Harsch E, Bongard O, Habicht F, Weimer D, Bounameaux H, Huber O, Chassot G, Morel P, Assimacopoulos-Jeannet F, and Golay A. Relationship between sympathetic reactivity and body weight loss in morbidly obese subjects. Int J Obes Relat Metab Disord 28: 906-911, 2004

13. Boozer CN, Daly PA, Homel P, Solomon JL, Blanchard D, Nasser JA, Strauss R, and Meredith T. Herbal ephedra/caffeine for weight loss: a 6-month randomized safety and efficacy trial. Int J Obes Relat Metab Disord 26: 593-604, 2002.

14. Boozer CN, Nasser JA, Heymsfield SB, Wang V, Chen G, and Solomon JL. An herbal supplement containing Ma Huang-Guarana for weight loss: a randomized, double-blind trial. Int J Obes Relat Metab Disord 25: 316-324, 2001.

15. Borchardt RT and Huber JA. Catechol Omethyltransferase. Structureactivity relationships for inhibition by flavonoids. J Med Chem 18: 120-122, 1975

16. Bouloumie A, Drexler HC, Lafontan M, and Busse R. Leptin, the product of Ob gene, promotes angiogenesis. Circ Res 83: 1059-1066, 1998.

17. Bracco D, Ferrarra JM, Arnaud MJ, Jequier E, and Schutz Y. Effects of caffeine on energy metabolism, heart rate, and methylxanthine metabolism in lean and obese women. Am J Physiol Endocrinol Metab 269: E671-E678, 1995.

18. Brakenhielm E, Cao R, Gao B, Angelin B, Cannon B, Parini P, and Cao Y. Angiogenesis inhibitor, TNP-470, prevents diet-induced and genetic obesity in mice. Circ Res 94: 1579-1588, 2004.

19. Bray GA. Autonomic and endocrine factors in the regulation of energy balance. Fed Proc 45: 1404-1410, 1986.

20. Bray GA. Reciprocal relation of food intake and sympathetic activity: experimental observations and clinical implications. Int J Obes 24 Suppl 2: S8-S17, 2000.

21. Bukowiecki L, Jahjah L, and Follea N. Ephedrine, a potential slimming drug, directly stimulates thermogenesis in brown adipocytes via betaadrenoreceptors. Int J Obes 6: 343-350, 1982.

22. Chantre $\mathbf{P}$ and Lairon $\mathbf{D}$. Recent findings of green tea extract AR25 (Exolise) and its activity for the treatment of obesity. Phytomedicine 9: 3-8, 2002.

23. Chen MD, Lin WH, Song YM, Lin PY, and Ho LT. Effect of caffeine on the levels of brain serotonin and catecholamine in the genetically obese mice. Zhonghua Yi Xue Za Zhi (Taipei) 53: 257-261, 1994.

24. Choo JJ. Green tea reduces body fat accretion caused by high-fat diet in rats through beta-adrenoceptor activation of thermogenesis in brown adipose tissue. J Nutr Biochem 14: 671-676, 2003.

25. Collins S, Kuhn CM, Petro AE, Swick AG, Chrunyk BA, and Surwit RS. Role of leptin in fat regulation. Nature 380: 677, 1996.

26. Curatolo PW and Robertson D. The health consequences of caffeine. Ann Intern Med 98: 641-653, 1983.

27. Diepvens K, Kovacs EM, Nijs IM, Vogels N, and Westerterp-Plantenga MS. Effect of green tea on resting energy expenditure and substrate oxidation during weight loss in overweight females. Br J Nutr 94: 1026-1034, 2005.

28. Dodt C, Lonnroth P, Fehm HL, and Elam M. The subcutaneous lipolytic response to regional neural stimulation is reduced in obese women. Diabetes 49: 1875-1879, 2000.

29. Dodt C, Lonnroth P, Wellhoner JP, Fehm HL, and Elam M. Sympathetic control of white adipose tissue in lean and obese humans. Acta Physiol Scand 177: 351-357, 2003.

30. Dulloo AG. Biomedicine. A sympathetic defense against obesity. Science 297: 780-781, 2002

31. Dulloo AG. Ephedrine, xanthines and prostaglandin-inhibitors: actions and interactions in the stimulation of thermogenesis. Int $J$ Obes Relat Metab Disord 17 Suppl 1: S35-S40, 1993.

32. Dulloo AG, Duret C, Rohrer D, Girardier L, Mensi N, Fathi M, Chantre $\mathbf{P}$, and Vandermander J. Efficacy of a green tea extract rich in catechin-polyphenols and caffeine in increasing 24-h energy expenditure and fat oxidation in humans. Am J Clin Nutr 70: 1040-1045, 1999.

33. Dulloo AG, Geissler CA, Horton T, Collins A, and Miller DS. Normal caffeine consumption: influence on thermogenesis and daily energy expenditure in lean and postobese human volunteers. Am J Clin Nutr 49: 44-50, 1989.

34. Dulloo AG and Jacquet J. An adipose-specific control of thermogenesis in body weight regulation. Int J Obes Relat Metab Disord 25 Suppl 5: S22-S29, 2001. 
35. Dulloo AG and Miller DS. Reversal of obesity in the genetically obese $\mathrm{fa} / \mathrm{fa}$ Zucker rat with an ephedrine/methylxanthines thermogenic mixture. J Nutr 117: 383-389, 1987.

36. Dulloo AG and Miller DS. The thermogenic properties of ephedrine/ methylxanthine mixtures: animal studies. Am J Clin Nutr 43: 388-394, 1986.

37. Dulloo AG and Miller DS. The thermogenic properties of ephedrine/ methylxanthine mixtures: human studies. Int J Obes 10: 467-481, 1986

38. Dulloo AG, Seydoux J, and Girardier L. Peripheral mechanisms of thermogenesis induced by ephedrine and caffeine in brown adipose tissue. Int J Obes 15: 317-326, 1991.

39. Dulloo AG, Seydoux J, and Girardier L. Potentiation of the thermogenic antiobesity effects of ephedrine by dietary methylxanthines: adenosine antagonism or phosphodiesterase inhibition. Metabolism 41: 1233 1241,1992

40. Dulloo AG, Seydoux J, Girardier L, Chantre P, and Vandermander J. Green tea and thermogenesis: interactions between catechin-polyphenols, caffeine and sympathetic activity. Int J Obes 24: 252-258, 2000.

41. Dulloo AG, Seydoux J, and Jacquet J. Adaptive thermogenesis and uncoupling proteins: a reappraisal of their roles in fat metabolism and energy balance. Physiol Behav 83: 587-602, 2004

42. Eikelis $\mathbf{N}$ and Esler M. The neurobiology of human obesity. Exp Physiol 90: 673-682, 2005.

43. Eikelis N, Lambert G, Wiesner G, Kaye D, Schlaich M, Morris M, Hastings J, Socratous F, and Esler M. Extra-adipocyte leptin release in human obesity and its relation to sympathoadrenal function. Am J Physiol Endocrinol Metab 286: E744-E752, 2004.

44. Eikelis N, Schlaich M, Aggarwal A, Kaye D, and Esler M. Interactions between leptin and the human sympathetic nervous system. Hypertension 41: 1072-1079, 2003.

45. Elmquist JK, Maratos-Flier E, Saper CB, and Flier JS. Unraveling the central nervous system pathways underlying responses to leptin. Nat Neurosci 1: 445-450, 1998.

46. Fassina G, Vene R, Morini M, Minghelli S, Benelli R, Noonan DM, and Albini A. Mechanisms of inhibition of tumor angiogenesis and vascular tumor growth by epigallocatechin-3-gallate. Clin Cancer Res 10: 4865-4873, 2004.

47. Flechtner-Mors M, Ditschuneit HH, Yip I, and Adler G. Sympathetic modulation of lipolysis in subcutaneous adipose tissue: effects of gender and energy restriction. J Lab Clin Med 134: 33-41, 1999.

48. Grassi G, Colombo M, Seravalle G, Spaziani D, and Mancia G. Dissociation between muscle and skin sympathetic nerve activity in essential hypertension, obesity, and congestive heart failure. Hypertension 31: 64-67, 1998 .

49. Grassi G, Seravalle G, Cattaneo BM, Bolla GB, Lanfranchi A, Colombo M, Giannattasio C, Brunani A, Cavagnini F, and Mancia G. Sympathetic activation in obese normotensive subjects. Hypertension 25: 560-563, 1995.

50. Haller CA and Benowitz NL. Adverse cardiovascular and centra nervous system events associated with dietary supplements containing ephedra alkaloids. N Engl J Med 343: 1833-1838, 2000.

51. Haller CA, Jacob P, and Benowitz NL. Short-term metabolic and hemodynamic effects of ephedra and guarana combinations. Clin Pharmacol Ther 77: 560-571, 2005.

52. Harada U, Chikama A, Saito S, Takase H, Nagao T, Hase T, and Tokimitsu I. Effects of the long-term ingestion of tea catechins on energy expenditure and dietary fat oxidation in healthy subjects. $J$ Health Sci 51: 248-252, 2005.

53. Hase T, Komine Y, Meguro S, Takeda Y, Takahashi H, Matsui Y, Inaoka S, Katsuragi Y, Tokimitsu I, Shimasaki H, and Itakura $\mathbf{H}$. Anti-obesity effects of tea catechins in humans. J Oleo Sci 50: 599-605, 2001 .

54. Haynes WG, Morgan DA, Djalali A, Sivitz WI, and Mark AL. Interactions between the melanocortin system and leptin in control of sympathetic nerve traffic. Hypertension 33: 542-547, 1999.

55. Haynes WG, Morgan DA, Walsh SA, Mark AL, and Sivitz WI. Receptor-mediated regional sympathetic nerve activation by leptin. J Clin Invest 100: 270-278, 1997.

56. Henry CJ and Emery B. Effect of spiced food on metabolic rate. Hum Nutr Clin Nutr 40: 165-168, 1986.

57. Hollands MA, Arch JRS, Phil D, and Cawthorne MA. A simple apparatus for comparative measurements of energy expenditure in human subjects: the thermic effect of caffeine. Am J Clin Nutr 34: 2291-2294, 1981
58. Hongu $\mathbf{N}$ and Sachan DS. Caffeine, carnitine and choline supplementation of rats decreases body fat and serum leptin concentration as does exercise. J Nutr 130: 152-157, 2000.

59. Horton TJ and Geissler CA. Post-prandial thermogenesis with ephedrine, caffeine and aspirin in lean, pre-disposed obese and obese women. Int J Obes Relat Metab Disord 20: 91-97, 1996.

60. Jansson PA, Larsson A, Smith U, and Lonnroth P. Glycerol production in subcutaneous adipose tissue in lean and obese humans. J Clin Invest 89: 1610-1617, 1992.

61. Jung RT, Shetty PS, James WPT, Barrand MA, and Callingham BA. Caffeine: its effect on catecholamines and metabolism in lean and obese humans. Clin Sci 60: 527-535, 1981.

62. Kao YH, Hiipakka RA, and Liao S. Modulation of endocrine systems and food intake by green tea epigallocatechin gallate. Endocrinology 141: 980-987, 2000.

63. Kawada T, Hagihara K, and Iwai K. Effects of capsaicin on lipid metabolism in rats fed a high fat diet. J Nutr 116: 1272-1278, 1986.

64. Kawada T, Sakabe S, Watanabe T, Yamamoto M, and Iwai K. Some pungent principles of spices cause the adrenal medulla to secrete catecholamine in anesthetized rats. Proc Soc Exp Biol Med 188: 229-233, 1988.

65. Kawada T, Watanabe T, Takaishi T, Tanaka T, and Iwai K. Capsaicin-induced beta-adrenergic action on energy metabolism in rats: influence of capsaicin on oxygen consumption, the respiratory quotient, and substrate utilization. Proc Soc Exp Biol Med 183: 250-256, 1986.

66. Kojima-Yuasa A, Hua JJ, Kennedy DO, and Matsui-Yuasa I. Green tea extract inhibits angiogenesis of human umbilical vein endothelial cells through reduction of expression of VEGF receptors. Life Sci 73: 1299-1313, 2003.

67. Kovacs EM, Lejeune MP, Nijs I, and Westerterp-Plantenga MS. Effects of green tea on weight maintenance after body-weight loss. $\mathrm{Br} J$ Nutr 91: 431-437, 2004.

68. Kurpad AV, Khan K, Calder AG, and Elia M. Muscle and whole body metabolism after norepinephrine. Am J Physiol Endocrinol Metab 266: E877-E884, 1994.

69. Lai HC, Chao WT, Chen YT, and Yang VC. Effect of EGCG, a major component of green tea, on the expression of Ets-1, c-Fos, and c-Jun during angiogenesis in vitro. Cancer Lett 213: 181-188, 2004.

70. Landsberg L. The sympathoadrenal system, obesity and hypertension: an overview. J Neurosci Methods 34: 179-186, 1990.

71. Landsberg $\mathbf{L}$ and Young JB. Diet and the sympathetic nervous system: relationship to hypertension. Int J Obes 5 Suppl 1: 79-91, 1981.

72. Landsberg $\mathbf{L}$ and Young JB. Sympathoadrenal activity and obesity: physiological rationale for the use of adrenergic thermogenic drugs. Int $J$ Obes Relat Metab Disord 17 Suppl 1: S29-S34, 1993.

73. Lejeune MPGM, Kovacs EMR, and Westerterp-Plantenga MS. Effect of capsaicin on substrate oxidation and weight maintenance after modest body-weight loss in human subjects. Br J Nutr 90: 1-10, 2003.

74. Macdonald IA. Advances in our understanding of the role of the sympathetic nervous system in obesity. Int J Obes Relat Metab Disord 19 Suppl 7: S2-S7, 1995.

75. Mantzoros CS, Qu D, Frederich RC, Susulic VS, Lowell BB, Maratos-Flier E, and Flier JS. Activation of beta(3) adrenergic receptors suppresses leptin expression and mediates a leptin-independent inhibition of food intake in mice. Diabetes 45: 909-914, 1996.

76. McCargar LJ, Clandinin MT, Fawcett DM, and Johnston JL. Shortterm changes in energy intake and serum insulin, neutral amino acids, and urinary catecholamine excretion in women. Am J Clin Nutr 47: 932-941, 1988 .

77. Molnar D, Torok K, Erhardt E, and Jeges S. Safety and efficacy of treatment with an ephedrine/caffeine mixture. The first double-blind placebo-controlled pilot study in adolescents. Int J Obes Relat Metab Disord 24: 1573-1578, 2000.

78. Nagao T, Komine Y, Soga S, Meguro S, Hase T, Tanaka Y, and Tokimitsu I. Ingestion of a tea rich in catechins leads to a reduction in body fat and malondialdehyde-modified LDL in men. Am J Clin Nutr 81: 122-129, 2005

79. Nagao T, Meguro S, Soga S, Otsuka A, Tomonobu K, Fumoto S, Chikama A, Mori K, Yuzawa M, Watanabe H, Hase T, Tanaka Y, Tokimitsu I, Shimasaki H, and Itakura H. Tea catechins suppress accumulation of body fat in humans. J Oleo Sci 50: 717-728, 2001.

80. Narkiewicz K, van de Borne PJ, Cooley RL, Dyken ME, and Somers VK. Sympathetic activity in obese subjects with and without obstructive sleep apnea. Circulation 98: 772-776, 1998. 
81. Ohnuki K, Haramizu S, Oki K, Watanabe T, Yazawa S, and Fushik T. Administration of capsiate, a non-pungent capsaicin analog, promotes energy metabolism and suppresses body fat accumulation in mice. Biosci Biotechnol Biochem 65: 2735-2740, 2001.

82. Ohnuki K, Niwa S, Maeda S, Inoue N, Yazawa S, and Fushiki T. CH-19 sweet, a non-pungent cultivar of red pepper, increased body temperature and oxygen consumption in humans. Biosci Biotechnol Biochem 65: 2033-2036, 2001.

83. Oku N, Matsukawa M, Yamakawa S, Asai T, Yahara S, Hashimoto F, and Akizawa T. Inhibitory effect of green tea polyphenols on membrane-type 1 matrix metalloproteinase, MT1-MMP. Biol Pharm Bull 26: 1235-1238, 2003.

84. Osaka T, Lee TH, Kobayashi A, Inoue S, and Kimura S. Thermogenesis mediated by a capsaicin-sensitive area in the ventrolateral medulla. Neuroreport 11: 2425-2428, 2000.

85. Pasman WJ, Westerterp-Plantenga MS, and Saris WHM. The effectiveness of long-term supplementation of carbohydrate, chromium, fibre and caffeine on weight maintenance. Int J Obes 21: 1143-1151, 1997.

86. Pasquali R, Baraldi G, Cesari MP, Melchionda N, Zamboni M, Stefanini C, and Raitano A. A controlled trial using ephedrine in the treatment of obesity. Int J Obes 9: 93-98, 1985.

87. Pasquali R, Casimirri F, Melchionda N, Grossi G, Bortoluzzi L, Morselli Labate AM, Stefanini C, and Raitano A. Effects of chronic administration of ephedrine during very-low-calorie diets on energy expenditure, protein metabolism and hormone levels in obese subjects. Clin Sci (Lond) 82: 85-92, 1992.

88. Pasquali R, Cesari MP, Melchionda N, Stefanini C, Raitano A, and Labo G. Does ephedrine promote weight loss in low-energy-adapted obese women? Int J Obes 11: 163-168, 1987.

89. Purdham DM, Zou MX, Rajapurohitam V, and Karmazyn M. Rat heart is a site of leptin production and action. Am J Physiol Heart Circ Physiol 287: H2877-H2884, 2004.

90. Racotta IS, Leblanc J, and Richard D. The effect of caffeine on food intake in rats: involvement of corticotropin-releasing factor and the sympatho-adrenal system. Pharmacol Biochem Behav 48: 887-892, 1994.

91. Rados C. Ephedra ban: no shortage of reasons. FDA Consum 38: 6-7, 2004.

92. Ramsey JJ, Colman RJ, Swick AG, and Kemnitz JW. Energy expenditure, body composition, and glucose metabolism in lean and obese rhesus monkeys treated with ephedrine and caffeine. Am J Clin Nutr 68: 42-51, 1998.

93. Ravussin E. Low resting metabolic rate as a risk factor for weight gain: role of the sympathetic nervous system. Int J Obes Relat Metab Disord 19 Suppl 7: S8-S9, 1995.

94. Ray S, Phadke S, Patel C, Hackman RM, and Stohs S. Short-term and long-term in vivo exposure to an ephedra- and caffeine-containing metabolic nutrition system does not induce cardiotoxicity in B6C3F1 mice. Arch Toxicol 79: 330-340, 2005.

95. Rayner DV and Trayhurn P. Regulation of leptin production: sympathetic nervous system interactions. J Mol Med 79: 8-20, 2001.

96. Robertson D, Frolich JC, Carr RK, Watson JT, Hollifield JW, Shand DG, and Oates JA. Effects of caffeine on plasma renin activity, catecholamines and blood pressure. N Engl J Med 298: 181-186, 1978.

97. Robertson D, Wade D, Workman R, Woosley RL, and Oates JA. Tolerance to the humoral and hemodynamic effects of caffeine in man. J Clin Invest 67: 1111-1117, 1981.

98. Roomi MW, Roomi N, Ivanov V, Kalinovsky T, Niedzwiecki A, and Rath M. Inhibitory effect of a mixture containing ascorbic acid, lysine, proline and green tea extract on critical parameters in angiogenesis. Oncol Rep 14: 807-815, 2005.

99. Rumantir MS, Vaz M, Jennings GL, Collier G, Kaye DM, Seals DR, Wiesner GH, Brunner-La Rocca HP, and Esler MD. Neural mechanisms in human obesity-related hypertension. J Hypertens 17: 11251133, 1999.

100. Saad MF, Alger SA, Zurlo F, Young JB, Bogardus C, and Ravussin E. Ethnic differences in sympathetic nervous system-mediated energy expenditure. Am J Physiol Endocrinol Metab 261: E789-E794, 1991.

101. Saper RB, Eisenberg DM, and Phillips RS. Common dietary supplements for weight loss. Am Fam Physician 70: 1731-1738, 2004.

102. Sartippour MR, Heber D, Henning S, Elashoff D, Elashoff R, Rubio $\mathbf{R}$, Zhang L, Norris A, and Brooks MN. cDNA microarray analysis of endothelial cells in response to green tea reveals a suppressive phenotype. Int J Oncol 25: 193-202, 2004.
103. Sartippour MR, Heber D, Zhang L, Beatty P, Elashoff D, Elashoff R, Go VL, and Brooks MN. Inhibition of fibroblast growth factors by green tea. Int J Oncol 21: 487-491, 2002.

104. Scherrer U, Randin D, Tappy L, Vollenweider P, Jequier E, and Nicod P. Body fat and sympathetic nerve activity in healthy subjects. Circulation 89: 2634-2640, 1994.

105. Shannon JR, Gottesdiener K, Jordan J, Chen K, Flattery S, Larson PJ, Candelore MR, Gertz B, Robertson D, and Sun M. Acute effect of ephedrine on 24-h energy balance. Clin Sci (Lond) 96: 483-491, 1999.

106. Shekelle PG, Hardy ML, Morton SC, Maglione M, Mojica WA, Suttorp MJ, Rhodes SL, Jungvig L, and Gagne J. Efficacy and safety of ephedra and ephedrine for weight loss and athletic performance: a meta-analysis. JAMA 289: 1537-1545, 2003.

107. Silha JV, Krsek M, Sucharda P, and Murphy LJ. Angiogenic factors are elevated in overweight and obese individuals. Int J Obes 29: 1308 1314, 2005.

108. Simonsen L, Bulow J, Madsen J, and Christensen NJ. Thermogenic response to epinephrine in the forearm and abdominal subcutaneous adipose tissue. Am J Physiol Endocrinol Metab 263: E850-E855, 1992.

109. Snitker S, Macdonald I, Ravussin E, and Astrup A. The sympathetic nervous system and obesity: role in aetiology and treatment. Obes Rev 1: $5-15,2000$

110. Spraul M, Ravussin E, Fontvieille AM, Rising R, Larson DE, and Anderson EA. Reduced sympathetic nervous activity. A potential mechanism predisposing to body weight gain. J Clin Invest 92: 1730-1735, 1993.

111. Tang FY, Nguyen N, and Meydani M. Green tea catechins inhibit VEGF-induced angiogenesis in vitro through suppression of VE-cadherin phosphorylation and inactivation of Akt molecule. Int J Cancer 106: 871-878, 2003

112. Toth MJ and Poehlman ET. Sympathetic nervous system activity and resting metabolic rate in vegetarians. Metabolism 43: 621-625, 1994.

113. Toubro S, Astrup AV, Breum L, and Quaade F. The acute and chronic effects of ephedrine/caffeine mixtures on energy expenditure and glucose metabolism in humans. Int J Obes 17 Suppl 3: S73-S77, 1993.

114. Toubro S, Astrup AV, Breum L, and Quaade F. safety and efficacy of long-term treatment with ephedrine, caffeine and an ephedrine/caffeine mixture. Int J Obes 17 Suppl 1: S69-S72, 1993.

115. Trayhurn P, Duncan JS, Hoggard N, and Rayner DV. Regulation of leptin production: a dominant role for the sympathetic nervous system? Proc Nutr Soc 57: 413-419, 1998.

116. Trayhurn P, Hoggard N, Mercer JG, and Rayner DV. Leptin: fundamental aspects. Int J Obes 23 Suppl 1: 22-28, 1999.

117. Tremblay A, Masson E, Leduc S, Houde A, and Despres JP. Caffeine reduces spontaneous energy intake in men but not in women. Nutr Res 8: $553-558,1988$.

118. Trompezinski S, Denis A, Schmitt D, and Viac J. Comparative effects of polyphenols from green tea (EGCG) and soybean (genistein) on VEGF and IL-8 release from normal human keratinocytes stimulated with the proinflammatory cytokine TNFalpha. Arch Dermatol Res 295: 112-116, 2003.

119. Tsi D, Nah AK, Kiso Y, Moritani T, and Ono H. Clinical study on the combined effect of capsaicin, green tea extract and essence of chicken on body fat content in human subjects. J Nutr Sci Vitaminol (Tokyo) 49: 437-441, 2003.

120. Tsuchida T, Itakura $\mathbf{H}$, and Nakamura $\mathbf{H}$. Leptin: fundamental aspects. Prog Med 22: 2189-2203, 2002.

121. Tulp OL and Buck CL. Caffeine and ephedrine stimulated thermogenesis in LA-corpulent rats. Comp Biochem Physiol C 85: 17-19, 1986.

122. van Soeren M, Mohr T, Kjaer M, and Graham TE. Acute effects of caffeine ingestion at rest in humans with impaired ephedrine responses. J Appl Physiol 80: 999-1005, 1996.

123. Vansal SS and Feller DR. Direct effects of ephedrine isomers on human beta-adrenergic receptor subtypes. Biochem Pharmacol 58: 807-810, 1999.

124. Vaz M, Jennings G, Turner A, Cox H, Lambert G, and Esler M. Regional sympathetic nervous activity and oxygen consumption in obese normotensive human subjects. Circulation 96: 3423-3429, 1997.

125. Voros G, Maquoi E, Demeulemeester D, Clerx N, Collen D, and Lijnen HR. Modulation of angiogenesis during adipose tissue development in murine models of obesity. Endocrinology 146: 4545-4554, 2005 . 
126. Watanabe T, Kawada T, Kurosawa M, Sato A, and Iwai K. Adrenal sympathetic efferent nerve and catecholamine secretion excitation caused by capsaicin in rats. Am J Physiol Endocrinol Metab 255: E23-E27, 1988.

127. Watanabe T, Kawada T, Yamamoto M, and Iwai K. Capsaicin, a pungent principle of hot red pepper, evokes catecholamine secretion from the adrenal medulla of anesthetized rats. Biochem Biophys Res Commun 142: 259-264, 1987.

128. Westerterp-Plantenga MS, Lejeune MP, and Kovacs EM. Body weight loss and weight maintenance in relation to habitual caffeine intake and green tea supplementation. Obes Res 13: 1195-1204, 2005.

129. Westerterp-Plantenga MS, Smeets A, and Lejeune MP. Sensory and gastrointestinal satiety effects of capsaicin on food intake. Int J Obes 29: 682-688, 2005.

130. White JE and Engel FL. A lipolytic action of epinephrine and norepinephrine on rat adipose tissue in vitro. Proc Soc Exp Biol Med 99. 375-378, 1958 .

131. World HE. Obesity: preventing and managing the global epidemic. Report of a WHO consultation. World Health Organ Tech Rep Ser 894: i-xii, 1-253, 2000.

132. Yamakawa S, Asai T, Uchida T, Matsukawa M, Akizawa T, and Oku N. (-)-Epigallocatechin gallate inhibits membrane-type 1 matrix metalloproteinase, MT1-MMP, and tumor angiogenesis. Cancer Lett 210: 47-55, 2004.

133. Yoshida T, Sakane N, Umekawa T, and Kondo M. Relationship between basal metabolic rate, thermogenic response to caffeine, and body weight loss following combined low calorie and exercise treatment in obese women. Int J Obes 18: 345-350, 1994.

134. Yoshida T, Yoshioka K, Wakabayashi Y, Nishioka H, and Kondo M. Effects of capsaicin and isothiocyanate on thermogenesis of interscapular brown adipose tissue in rats. J Nutr Sci Vitaminol (Tokyo) 34: 587-594, 1988 .

135. Yoshioka M, Doucet E, Drapeau V, Dionne I, and Tremblay A. Combined effects of red pepper and caffeine consumption on $24 \mathrm{~h}$ energy balance in subjects given free access to foods. Br J Nutr 85: 203-211, 2001

136. Yoshioka M, Lim K, Kikuzato S, Kiyonaga A, Tanaka H, Shindo M, and Suzuki M. Effects of red-pepper diet on the energy metabolism in men. J Nutr Sci Vitaminol (Tokyo) 41: 647-656, 1995.

137. Yoshioka M, St-Pierre S, Drapeau V, Dionne I, Doucet E, Suzuki M, and Tremblay A. Effects of red pepper on appetite and energy intake. Br J Nutr 82: 115-123, 1999.

138. Yoshioka M, St-Pierre S, Suzuki M, and Tremblay A. Effects of red pepper added to high-fat and high-carbohydrate meals on energy metabolism and substrate utilization in Japanese women. Br J Nutr 80: 503-510, 1998.

139. Young JB and Macdonald IA. Sympathoadrenal activity in human obesity: heterogeneity of findings since 1980. Int J Obes Relat Metab Disord 16: 959-967, 1992.

140. Zheng G, Sayama K, Okubo T, Juneja LR, and Oguni I. Anti-obesity effects of three major components of green tea, catechins, caffeine and theanine, in mice. In Vivo 18: 55-62, 2004.

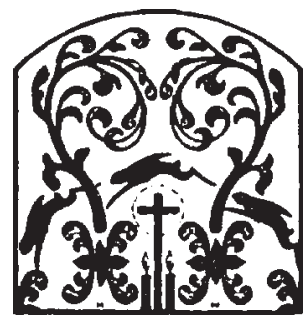

